\title{
Influence of Moisture Content of Feedstock Materials on Briquettes Properties
}

Milan Brožek

Department of Material Science and Manufacturing Technology, Faculty of Engineering, Czech University of Life Sciences Prague. Kamýcká 129, 16521 Praha 6 - Suchdol, Czech Republic. E-mail: brozek@tf.czu.cz

Current contribution contains of results of experimental measurements performed within the determination of initial raw feedstock materials moisture content and its influence on final properties of subsequently produced briquettes. A birch wood chips samples with five different moisture contents, specifically 5.0\%, 7.6\%, 16.7\%, $\mathbf{1 9 . 0} \%$ and $\mathbf{2 7 . 7} \%$, were used for experimental investigations. Investigated briquette samples were produced by hydraulic high-pressure briquetting press Briklis, type BrikStar 30-12 with cylindrical pressing chamber of 50 mm. All investigated briquette samples were produced under the same conditions with constant adjustment of all parameters of used briquetting press. A basic physical-mechanical properties of investigated briquette samples were used as a criteria of investigations evaluation. All measured values were subjected to the statistical analysis. Final evaluation of measured values indicated that best results were achieved by briquette samples produced from feedstock material with moisture content equal to $7.6 \%$. Evaluation of current investigation also proved that if moisture content was higher or lower, the quality of produced briquette samples decreased.

Keywords: birch wood chips, ash amount, gross calorific value, total moisture content, density, rupture force

\section{Acknowledgement}

The research has been supported by the project "Statement of suitability of exotic and local waste biomass for solid biofuel production within its energy potential evaluation (Stanovení vhodnosti exotické i lokální odpadní biomasy $k$ produkci tuhých biopaliv na základě zhodnocení jejího energetického potenciálu)”, financed by IGA, Faculty of Engineering, CULS Prague, Nr. 2017:31140/1312/3112.

\section{References}

[1] AVELAR, N. V., REZENDE, A. A. P., CARNEIRO, A. D. C. O., SILVA, C. M. (2016). Evaluation of briquettes made from textile industry solid waste. Renewable Energy. 91, 417-424.

[2] BASORE, C. A. (1929). Fuel briquettes from Southern pine sawdust. Auburn, Alabama Polytechnic Institute. 30.

[3] BLAHOVEC, J. (1982). Stlačování upravené žitné slámy (Compressing conditioned rye straw). Zemědělská technika. 28, 2, 65-75. (in Czech).

[4] BROŽEK, M. (2013). Properties of briquettes from paper waste. Manufacturing Technology. 13, 2, $138-142$.

[5] BROŽEK, M. (2013). Study of briquettes properties at their long-time storage. Journal of Forest Science, 59, 3, 101-106.

[6] BROŽEK, M. (2015). Briquettes made from wood residues. Manufacturing Technology. 15, 2, 126-130.

[7] BROŽEK, M. (2015). Evaluation of selected properties of briquettes from recovered paper and board. Research in Agriculture Engineering, 61, 2, 66-71.

[8] BROŽEK, M., NOVÁKOVÁ, A., KOLÁŘOVÁ, M. (2012). Quality evaluation of briquettes made from wood waste. Research in Agricultural Engineering, 58, 1, 30-35.

[9] CHEN, L., XING, L., HAN, L. (2009). Renewable energy from agro-residues in China: Solid biofuels and biomass briquetting technology. Renewable and Sustainable Energy Reviews, 13, 9, 2689-2695.

[10] FELFLI, F. F., MESA, P. J. M., ROCHA, J. D., FILIPETTO, D., LUENGO, C. A., PIPPO, W. A. (2011). Biomass briquetting and its perspectives in Brazil. Biomass and Bioenergy, 35, 1, 236-242.

[11] GUO, L., TABIL, L. G., WANG, D., WANG, G. (2016). Influence of moisture content and hammer mill screen size on the physical quality of barley, oat, canola and wheat straw briquettes. Biomass and Bioenergy. 94, 201208.

[12] HUSAIN, Z., ZAINAC, Z., ABDULLAH, Z. (2002). Briquetting of palm fibre and shell from the processing of palm nuts to palm oil. Biomass and Bioenergy, 22, 6, 505-509.

[13] KARKANIA, V., FANARA, E., ZABANIOTOU, A. (2012). Review of sustainable biomass pellets production A study for agricultural residues pellets' market in Greece. Renewable and Sustainable Energy Reviews. 16, 3, 1426-1436. 
[14] KOLÁŘOVÁ, M. (2011). Vlastnosti pelet a briket pro energetické využití (Properties of pellets and briquettes for energy recovery). Dissertation, Czech University of Life Sciences Prague. 1-121.

[15] LEHTIKANGAS, P. (2001). Quality properties of pelletised sawdust, logging residues and bark. Biomass and Bioenergy. 20, 5, 351-360.

[16] LEHTIKANGAS, P. (2000). Storage effects on pelletised sawdust, logging residues and bark. Biomass and Bioenergy. 19, 5, 287-293.

[17] LI, X., MUPONDWA, E., PANIGRAHI, S., TABIL, L., ADAPA, P. (2012). Life cycle assessment of densified wheat straw pellets in the Canadian Prairies. International Journal of Life Cycle Assessment. 17, 4, 420-431.

[18] MATÚŠ, M., ŠOOŠ, L., KRIŽAN, P., BENIAK, J., ONDRUŠKA, J. (2015). Design theory for screw geometry in a briquette press. Manufacturing Technology. 15, 3, 384-391.

[19] NOVÁKOVÁ, A., BROŽEK, M. (2008). Mechanical properties of pellets from sorrel. In: Engineering for rural development. Jelgava, Latvia University of Agriculture, Faculty of Engineering, 265-269.

[20] OBI, O. F., OKONGWU, K. C. (2016). Characterization of fuel briquettes made from a blend of rice husk and palm oil mill sludge. Biomass Conversion and Biorefinery. 6, 4, 449-456.

[21] PLÍŠTIL, D. (2005). Briketování a paketování (Briquetting and packeting). Dissertation, Czech University of Life Sciences Prague. 1-169.

[22] SHERIDAN, E. T., BERTE, V. C. (1959). Fuel-briquetting and packaged-fuel plants in the United States that reported. Washington, U. S. Government Printing Office. 7.

[23] SHUMA, R., MADYIRA, D. M. (2017). Production of Loose Biomass Briquettes from Agricultural and Forestry Residues. Procedia Manufacturing. 7, 98-105.

[24] STOLARSKI, M. J., SZCZUKOWSKI, S., TWOKOWSKI, J., KRZYŽANIAK, M., GULCZYŇSKI, P., MLECZEK, M. (2013). Comparison of quality and production cost of briquettes made from agricultural and forest origin biomass. Renewable energy, 57, 1, 20-26.

[25] TRIPATHI, A. K., IYER, P. V. R., KANDPAL, T. C. (1998). A techno-economic evaluation of biomass briquetting in India. Biomass and Bioenergy, 14, 5-6, 479-488.

[26] WHITTAKER, C., SHIELD, I. (2017). Factors affecting wood, energy grass and straw pellet durability - A review. Renewable and Sustainable Energy Reviews. 71, 1-11.

[27] ČSN EN 14775 (2010). Tuhá biopaliva (Solid biofuels) - Stanovení obsahu popela (Determination of ash content). ČNI.

[28] ČSN EN 14918 (2010). Tuhá biopaliva (Solid biofuels) - Stanovení spalného tepla a výhřevnosti (Determination of combustion heat and calorific value). ČNI.

[29] ČSN EN 14961-1 (2010). Tuhá biopaliva (Solid biofuels) - Specifikace a tř́́dy paliv (Fuel specifications and classes) - Část 1 (Part 1): Obecné požadavky (General requirements). ČNI.

[30] ČSN EN 15210-2 (2011). Tuhá biopaliva (Solis biofuels) - Metody stanovení mechanické odolnosti pelet a briket (Methods for the determination of mechanical durability of pellets and briquettes) - Č́st 2 (Part 2): Brikety (Briquettes). ČNI.

[31] ČSN EN ISO 18134-2 (2016). Tuhá biopaliva (Solid biofuels) - Stanovení obsahu vody (Determination of moisture content) - Metoda sušení v sušárně (Oven dry method) - Část 2 (Part 2): Celková voda (Total moisture) Zjednodušená metoda (Simplified method). ČNI.

[32] MŽP ČR 2009. Směrnice č. 14/2009. Brikety z dřevního odpadu (Briquettes from wood waste). Praha, Ministerstvo životního prostředí České republiky.

[33] BRIKLIS. Briketovací lisy BrikStar. (Briquetting presses BrikStar). [Online]. Available at: http://www.briklis.cz/produkty/na-drevo/hydraulicke-briketovaci-lisy/brikstar.html. [Accessed 2016 October 09]. 